Original Article

\title{
Impact of a large dam on reproduction of a non-migratory teleost species, Acestrorhynchus lacustris (Characiformes: Acestrorhynchidae)
}

\author{
Impacto de uma grande barragem na reprodução de uma espécie de teleósteo não \\ migradora, Acestrorhynchus lacustris (Characiformes: Acestrorhynchidae).
}

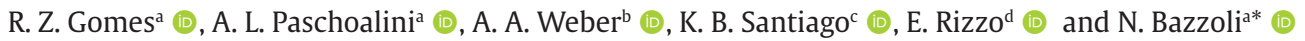 \\ a Pontifícia Universidade Católica de Minas Gerais - PUC Minas, Instituto de Ciências Biológicas e da Saúde, Programa de Pós-graduação em Biologia \\ de Vertebrados, Belo Horizonte, MG, Brasil \\ ' University of California, Department of Pharmacology, Robert Tukey Lab, San Diego, CA, United States \\ 'Centro Integrado de Recursos Pesqueiros e Aquicultura de Três Marias - CODEVASF, Três Marias, MG, Brasil \\ ${ }^{\mathrm{d} U n i v e r s i d a d e ~ F e d e r a l ~ d e ~ M i n a s ~ G e r a i s ~-~ U F M G, ~ I n s t i t u t o ~ d e ~ C i e ̂ n c i a s ~ B i o l o ́ g i c a s, ~ D e p a r t a m e n t o ~ d e ~ M o r f o l o g i a, ~ L a b o r a t o ́ r i o ~ d e ~ I c t i o h i s t o l o g i a, ~ B e l o ~}$ \\ Horizonte, MG, Brasil
}

\begin{abstract}
The release of water from the reservoir hypolimnion, lower concentration of oxygen and the anthropogenic regulation of the river flow, could affect the reproduction of fish, especially migratory species. However, little is known about the effects of these changes in water on non-migratory species. In this sense, the reproduction of Acestrohynchus lacustris was evaluated in two sections of São Francisco River, Minas Gerais, Brazil. Section 1, located immediately downstream from Três Marias Dam (18 $09^{\prime} 31.65^{\prime \prime S}$ and $\left.45^{\circ} 13^{\prime} 36.00^{\prime \prime} \mathrm{W}\right)$ and section 2, located at the confluence of the São Francisco and the Abaeté Rivers ( $18^{\circ} 02^{\prime} 47.78^{\prime \prime} \mathrm{S}$ and $45^{\circ} 10^{\prime} 57.95^{\prime \prime} \mathrm{W}$ ). For this, we obtained the physico-chemical parameters of water of each study section. Additionally, biometric data and biological indices of all specimens were measured. Fecundity and follicles diameters were measured in females. Temperature, dissolved oxygen and flow showed lower values in section 1. Fish captured in this section, had lower values of GSI in both sexes, and females presented decreased values of fecundity and follicles diameter. This species showed reproductive activity in the two sections analyzed, however, in section 1 where the temperature and dissolved oxygen presented significant lower values, the reproductive capacity of A. lacustris, was negatively affected.
\end{abstract}

Keywords: hypolimnion, fecundity, dogfish, neotropical fish, Três Marias Dam.

\begin{abstract}
Resumo
A liberação de água do hipolímnio do reservatório, baixa concentração de oxigênio e a regulação antropogênica do fluxo do rio podem afetar a reprodução de peixes, principalmente espécies migradoras. No entanto, pouco se sabe sobre os efeitos dessas mudanças nas condições da água em espécies não migradoras. A reprodução de Acestrohynchus lacustris foi avaliada em duas seções do rio São Francisco. Seção 1, localizada imediatamente a jusante da barragem de Três Marias e seção 2, localizada na confluência dos rios São Francisco e Abaeté. Para isso, foram obtidos os parâmetros físico-químicos da água de cada seção do estudo. Além disso, dados biométricos e índices biológicos de todos os peixes capturados foram obtidos. Adicionalmente, nas fêmeas foram medidos os diâmetros dos folículos vitelogênicos e a fecundidade. Temperatura, oxigênio dissolvido e fluxo apresentaram valores mais baixos na seção 1. Os peixes capturados nesta seção apresentaram menores valores de IGS em ambos os sexos, e as fêmeas apresentaram menores valores de fecundidade e diâmetro dos folículos. Essa espécie apresentou atividade reprodutiva nas duas seções analisadas, porém, na seção 1, onde os parâmetros da água apresentam piores condições para o processo reprodutivo de peixes, a capacidade reprodutiva de A. lacustris foi afetada negativamente.
\end{abstract}

Palavras-chave: hipolímnio, fecundidade, peixe-cachorro, peixes neotropicais, Barragem de Três Marias.

\section{Introduction}

River damming is considered one of the main impacts on riverine ecosystems due to the alteration in physical and chemical parameters of the water, as well the

anthropogenic regulation of the natural flow of the river, thus influencing the reproduction and behaviour of fishes (Cetra and Petrere Junior, 2006; Agostinho et al., 2008;

*e-mail: bazzoli@pucminas.br

Received: July 13, 2020 - Accepted: November 4, 2020 
Abujanra et al., 2009; Olden and Naiman, 2010; Paschoalini et al., 2013; Perini et al., 2013). It is known that alterations in the temperature and hydrological dynamics of rivers can negatively affect the reproductive activity and other biological processes of several freshwater fish with long-term deleterious effects in the aquatic community (Arenzon et al., 2002). For example, the colder temperature of the water downstream from reservoirs may affect the gonadal development, ovarian follicle diameter, fecundity and gonads growth in fish (Armstrong and Witthames, 2012; Kolm and Ahnesjö, 2005).

This type of impact on fish has already been reported in rivers in others regions of the world, for example China (Yi et al., 2014) and French Guiana (Ponton, 1998). Recent studies in Brazil have shown that the reproduction of migratory and non-migratory small forage fishes was negatively impacted in the first kilometers downstream from the Três Marias Dam, where the temperature and dissolved oxygen of the water are lower in the summer due to thermal stratification of the reservoir in this period (Arantes et al., 2010; Domingos et al., 2012; Normando et al., 2014; Thomé et al., 2012). However, these studies also showed that approximately $24 \mathrm{~km}$ downstream from Três Marias Dam, after the confluence with Abaeté River, the biotic and abiotic conditions of the water become favourable to the reproduction of migratory and non-migratory species.

Despite the fact that most studies are conducted with migratory fish, there are few studies on Neotropical rivers that have assessed the effects of dams on the reproduction of resident or non-migratory fish (Bazzoli et al., 2019; Donaldson et al., 2008). The Acestrorhynchus lacustris (Lütken, 1875), popularly known as dogfish, is a nonmigratory species, inhabiting the Paraná and São Francisco Rivers basins, two important South American basins. This species can reach $27 \mathrm{~cm}$ (Menezes, 2003) and has an important ecological role in the food chain, serving as prey for large piscivorous fish and controlling small fish populations (Hahn et al., 2000). Additionally, A. lacustris presents a long reproductive period and batch fecundity, reproducing throughout the year (Godinho et al., 2009).

Given the ecological importance of this species and the lack of studies focusing in reproductive biology of nonmigratory species influenced by dams, the present study aimed to assess the seasonal variation in reproductive activity and how the alterations in water parameters downstream Três Marias Dam influence the reproduction of A. lacustris from São Francisco River, a very important river in Neotropical region.

\section{Materials and Methods}

\subsection{Sampling}

The specimens were captured, bimonthly, between May 2011 and June 2012 in two sections of the São Francisco River: section 1, immediately downstream of Três Marias Dam (18 $09^{\prime} 31.65^{\prime \prime}$ S and $\left.45^{\circ} 13^{\prime} 36.00^{\prime \prime} \mathrm{W}\right)$ and section 2, downstream of confluence of São Francisco and Abaeté River ( $18^{\circ} 02^{\prime} 47.78^{\prime \prime} \mathrm{S}$ and $45^{\circ} 10^{\prime} 57.95^{\prime \prime W}$ ) (see Figure 1).
A total of 521 specimens were captured. 127 females and 116 males from section 1, and 134 females and 144 males from section 2 .

The fish were captured using gillnets with $3-6 \mathrm{~cm}$ between opposite knots and were immediately transported to the Integrated Center for Fisheries Resources and Aquaculture of Três Marias - CODEVASF. The specimen, if alive, were anesthetized with Eugenol (Fernandes et al., 2016) and then euthanized by transversal section of the cervical medulla, following the ethical principles of animal handling established by the Brazilian College for Animal Experimentation (COBEA). For each specimen, the following parameters were recorded: total length (TL; accuracy: 1cm), body weight (BW; accuracy: $0.01 \mathrm{~g}$ ) and gonadal weight (GW; accuracy: 0.01g). Ten voucher specimens were sent to Natural Sciences Museum of Pontifícia Universidade Católica de Minas Gerais, Brazil (MCNIP-0624, 0653, 0743).

\subsection{Biological indices}

To determine the gonadal volume for mature males and females, the gonadosomatic index (GSI) was calculated (Gonadosomatic index - GSI $=$ Gonadal weight /Body weight $x$ 100). Fulton's condition factor (Fulton's condition factor $-\mathrm{K}=$ Body weight/Total length ${ }^{3}$ x 100) (Lizama and Ambrosio, 2002) was also calculated to compare the health status of the males and females between sampling sections.

\subsection{Physical-chemical parameters of the water}

The physical and chemical parameters of the water from the two sections of the São Francisco River were recorded bimonthly ( $\mathrm{n}=7)$, on the same day and same sections as fish sampling occurred. The following parameters were measured, at $1.5 \mathrm{~m}$ depth, with a Horiba U-10 probe: $\mathrm{pH}$, temperature $\left({ }^{\circ} \mathrm{C}\right)$, dissolved oxygen $(\mathrm{mg} / \mathrm{L})$ and electrical conductivity $(\mu \mathrm{S} / \mathrm{cm})$. The water flow $\left(\mathrm{m}^{3} / \mathrm{s}\right)$ values were supplied by Companhia Energética de Minas Gerais (CEMIG).

\subsection{Gonadal maturation stages and follicular diameter}

To assess de seasonal variation in reproductive activity, the gonadal maturation stages of males and females were determined bimonthly through the macro and microscopic features of gonads and the changes in the gonadosomatic index according to Carvalho et al. (2009). For microscopic analyses, gonad fragments of all specimens captured were previously fixed in Bouin's solution and subsequently submitted to histological routine, embedding in paraffin, $5 \mu \mathrm{m}$ thick microtome sections and staining in haematoxylin-eosin (HE).

The diameters of 50 vitellogenic follicles (DVF) were obtained from mature ovaries of 10 specimens from each sampling section, using an ocular micrometer attached to a light microscope. Only intact vitellogenic follicles, with little shrinkage and with the nucleus visible were measured (Arantes et al., 2010).

\subsection{Fecundity}

In order to determine the batch fecundity, samples from the middle region of 20 mature females from each section 


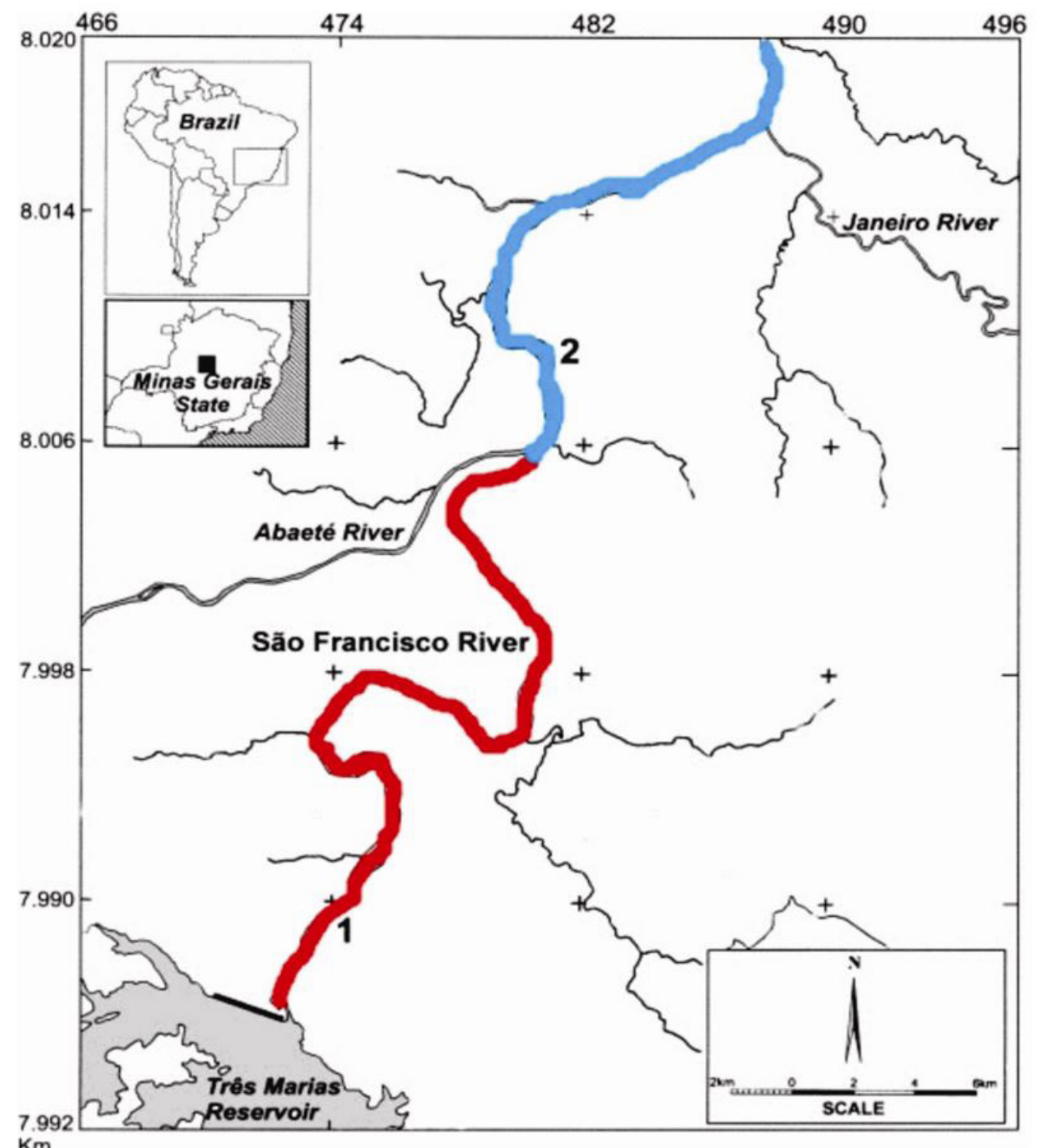

Figure 1. Sampling sections of the São Francisco River, downstream from Três Marias Dam. Section 1: immediately downstream the Dam; Section 2: immediately after the confluence with Abaeté River. UTM coordinates.

were fixed in modified Gilson's solution ( $100 \mathrm{ml}$ of $60 \%$ ethanol, $880 \mathrm{ml}$ distilled water, $15 \mathrm{ml}$ of $80 \%$ nitric acid, $18 \mathrm{ml}$ of glacial acetic acid and $20 \mathrm{~g}$ of mercury chloride) until the complete dissociation of the follicles. With the aid of a stereoscopic microscope, the vitellogenic follicles were separated from the others by their opaque colour and counted. The batch fecundity (BF) was determined by the expression: $B F=V F \times G W$, in which $V F=$ number of vitellogenic follicles per ovary gram and $\mathrm{GW}=$ gonadal weight (Melo et al., 2011). Relative fecundity with body weight was estimated by the expression: $\mathrm{RF}=\mathrm{BF} / \mathrm{BW}$, where $\mathrm{BF}=$ batch fecundity, $\mathrm{BW}=$ body weight.

\subsection{Statistical analyses}

We conducted the Lilliefors test for all studied parameters in order to determine the normality of data. Then, to analyse the variables between sections, we used the T-student test for physical and chemical water parameters and the Mann-Whitney to compare biological data. For the comparison between sizes classes of vitellogenic follicles, we used the Kruskal-Wallis test followed by the post hoc Dunn test.

Biometric data, GSI, fecundity, vitellogenic follicle diameters, maturation stages and abiotic factors are expressed in tables and graphs with mean \pm standard deviation (SD). A significance level of $\mathrm{p}<0.05$ was used for all analysed tests. Statistical analyses and graphs were done by software GraphPad Prism 7.0 for windows.

\section{Results}

\subsection{Physical and chemical parameters of the water}

The physical and chemical parameters analysed showed that the temperature, dissolved oxygen and 
flow presented higher mean values in section 2 , with significant statistical differences in relation to the values of section 1 . However, electrical conductivity and $\mathrm{pH}$ showed no statistical difference between sections (see Table 1).

\subsection{Biometry, biological indices and fecundity}

Regarding to total length and body weight, females and males did not show statistical variations between sections 1 and 2 . The GSI (mean \pm SD) of mature females and males presented statistical differences between sections. On the other hand, Fulton's condition factor did not show significant difference between sampling sections for both sexes (as shown in Tables 2 and 3 ). The batch fecundity (BF) also presented significant statistical differences between sampling sections, showing high values in female fish from section 2 (as shown in Table 2 ).

The vitellogenic follicles of A. lacustris collected had an average diameter of $733.6 \pm 52.7 \mu \mathrm{m}$ in section 1 and $786.1 \pm 65.9 \mu \mathrm{m}$ in section 2 , with statistical difference between them (as shown in Table 2). It was determined four size classes of vitellogenic follicles of this species and size class with the highest number of follicles was 700-860 $\mu \mathrm{m}$ (see Figure 2).

\subsection{Gonadal maturation stages}

The following macro and microscopic features of each maturation stages were identified for females: resting $\mathrm{F} 1=$ thin, translucent and less vascularised ovaries with

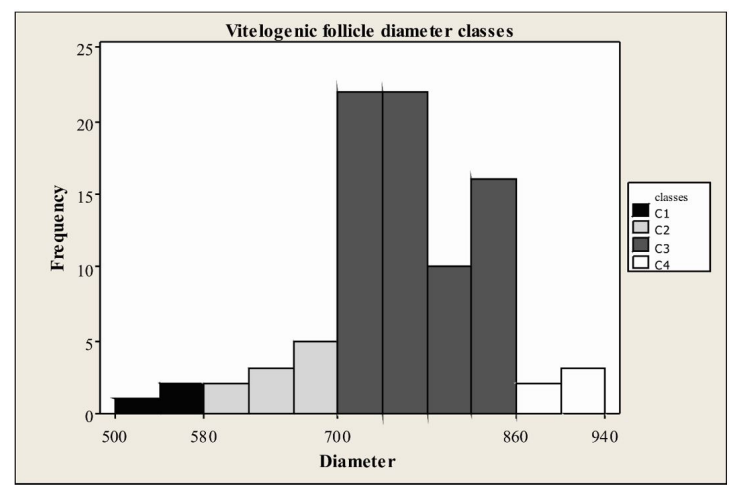

Figure 2. Frequency (\%) and size classes of vitelogenic follicles ( $\mu \mathrm{m}$ ) of A. lacustris from fully grown ovaries of A. lacustris. Different bar colours indicate statistically significant differences between the diameter classes $(\mathrm{p}<0.05)$.

Table 1. Physical and chemical parameters of two sampled sections downstream Três Marias Dam, São Francisco River.

\begin{tabular}{lccccc}
\hline & \multicolumn{2}{c}{ Section 1 } & & \multicolumn{2}{c}{ Section 2 } \\
\cline { 2 - 3 } \cline { 5 - 6 } & Mean \pm SD & Range & & Mean \pm SD & Range \\
\hline Temperature $\left({ }^{\circ} \mathrm{C}\right)$ & $23.21 \pm 0.57^{\mathrm{a}}$ & $22.68-24.00$ & & $24.31 \pm 0.71^{\mathrm{b}}$ & $23.58-25.40$ \\
Dissolved Oxygen $(\mathrm{mg} / \mathrm{L})$ & $5.55 \pm 1.67^{\mathrm{a}}$ & $4.13-8.12$ & & $7.97 \pm 0.55^{\mathrm{b}}$ & $7.33-8.65$ \\
$\mathrm{pH}($ Sorensen) & $5.83 \pm 0.46^{\mathrm{a}}$ & $5.12-6.24$ & & $6.35 \pm 0.51^{\mathrm{a}}$ & $5.62-7.02$ \\
Electrical conductivity $(\mu \mathrm{S} / \mathrm{cm})$ & $68.6 \pm 1.5^{\mathrm{a}}$ & $67.00-71.00$ & & $64.2 \pm 7.19^{\mathrm{a}}$ & $56.00-74.00$ \\
Flow $\left(\mathrm{m}^{3} / \mathrm{s}\right)$ & $693.22 \pm 100.58^{\mathrm{a}}$ & $584.93-798.22$ & & $815.13 \pm 52.71^{\mathrm{b}}$ & $724.57-854.51$ \\
\hline
\end{tabular}

Different letters indicate statistical difference between sections $(\mathrm{p}<0.05) . \mathrm{SD}=$ standard deviation.

Table 2. Biological and reproductive data of A. lacustris females in two sections of São Francisco River.

\begin{tabular}{|c|c|c|c|c|}
\hline \multirow{3}{*}{$\begin{array}{c}\text { Females } \\
\mathbf{N}\end{array}$} & \multicolumn{2}{|c|}{ Section 1} & \multicolumn{2}{|c|}{ Section 2} \\
\hline & \multicolumn{2}{|c|}{127} & \multicolumn{2}{|c|}{134} \\
\hline & Mean \pm SD & Range & Mean \pm SD & Range \\
\hline $\mathrm{TL}(\mathrm{cm})$ & $20.69 \pm 1.76^{a}$ & $14.2-24.8$ & $21.01 \pm 2.4^{\mathrm{a}}$ & $14.4-25.9$ \\
\hline BW (g) & $80.24 \pm 27.9^{a}$ & $25.8-158$ & $86.65 \pm 28.9^{a}$ & $24.4-135.0$ \\
\hline GSI (\%) & $2.92 \pm 0.76^{\mathrm{a}}$ & $0.98-3.89$ & $4.37 \pm 1.12^{\mathrm{b}}$ & $3.0-7.1$ \\
\hline $\mathrm{FD}(\mu \mathrm{m})$ & $733.6 \pm 52.75^{a}$ & $622.6-822.4$ & $786.1 \pm 65.96^{b}$ & $702.2-925.2$ \\
\hline $\mathrm{BF}$ & $2,587 \pm 911^{\mathrm{a}}$ & $996-4,809$ & $4,179 \pm 1,889^{b}$ & $2,156-7,854$ \\
\hline $\mathrm{K}$ & $0.96 \pm 0.20^{\mathrm{a}}$ & $0.63-2.9$ & $0.93 \pm 0.11^{\mathrm{a}}$ & $0.65-1.25$ \\
\hline
\end{tabular}

Different letters indicate statistical difference between sections $(\mathrm{p}<0.05)$. $\mathrm{N}=$ number of individuals; $\mathrm{SD}=$ standard deviation; $\mathrm{TL}=$ total length; $\mathrm{BW}=$ body weight; $\mathrm{GSI}=$ gonadosomatic index; $\mathrm{FD}=$ Follicular diameter; $\mathrm{BF}=$ Batch fecundity; $\mathrm{K}=$ Fulton's condition factor.

Table 3. Biological and reproductive data of A. lacustris males in two sections of São Francisco River.

\begin{tabular}{|c|c|c|c|c|}
\hline Males & \multicolumn{2}{|c|}{ Section 1} & \multicolumn{2}{|c|}{ Section 2} \\
\hline \multirow[t]{2}{*}{$\mathbf{N}$} & \multicolumn{2}{|c|}{116} & \multicolumn{2}{|c|}{144} \\
\hline & Mean \pm SD & Range & Mean \pm SD & Range \\
\hline $\mathrm{TL}(\mathrm{cm})$ & $16.6 \pm 1.4^{\mathrm{a}}$ & $14.0-21.0$ & $16.9 \pm 1.5^{\mathrm{a}}$ & $13.8-20.8$ \\
\hline $\mathrm{BW}(\mathrm{g})$ & $39.5 \pm 14.4^{\mathrm{a}}$ & $15.0-85$ & $40.8 \pm 12.7^{a}$ & $20.0-90.0$ \\
\hline GSI (\%) & $0.64 \pm 0.29^{a}$ & $0.03-1.0$ & $1.01 \pm 0.48^{\mathrm{b}}$ & $0.43-2.37$ \\
\hline $\mathrm{K}$ & $0.86 \pm 0.10^{\mathrm{a}}$ & $0.51-1.1$ & $0.84 \pm 0.09^{a}$ & $0.69-1.20$ \\
\hline
\end{tabular}

Different letters indicate statistical difference between sections $(\mathrm{p}<0.05) . \mathrm{N}=$ number of individuals; $\mathrm{SD}=\mathrm{standard}$ deviation; $\mathrm{TL}=$ total length; $\mathrm{BW}=$ body weight; GSI= gonadosomatic index; K= Fulton's condition factor. 

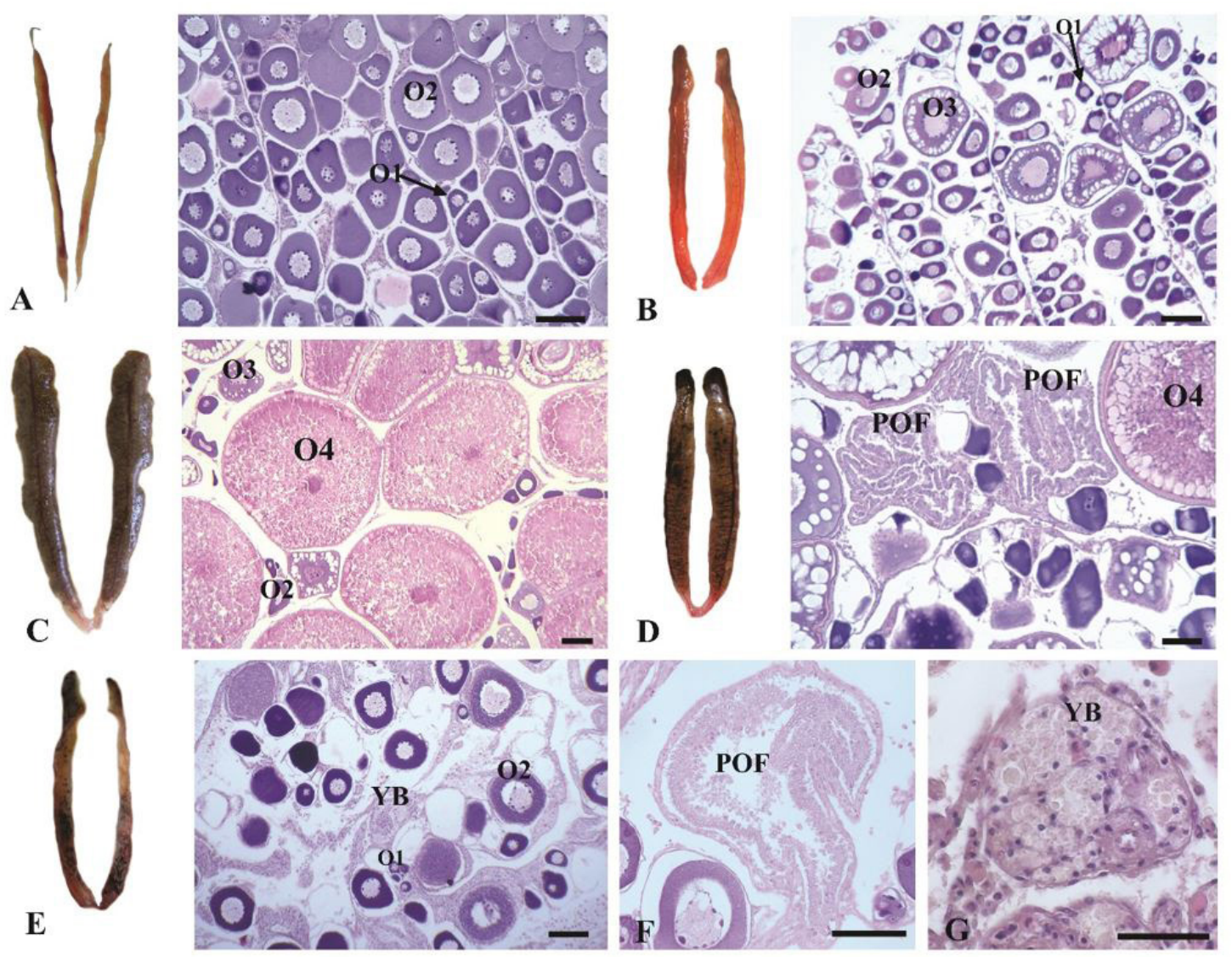

Figure 3. Ovaries in different maturation stages and the respective transversal sections stained by HE. (A) resting, (B) initial maturation, (C) advanced maturation/mature, (D) partially spawned, (E) totally spawned ovaries, (F) post-ovulatory follicle, (G) yellow body. O1= early perinucleolar follicles; $02=$ late perinucleolar follicles; $\mathrm{O3}=$ pre-vitellogenic follicles; $\mathrm{O}=$ = vitellogenic follicles; POF= post-ovulatory follicle; YB= yellow body. Scales bars represent $100 \mu \mathrm{m}$.

initial follicles (01) and advanced $(\mathrm{O} 2)$ perinucleolar (see Figure 3A); initial maturation - F2= voluminous, orange ovaries, and histologically containing initial perinucleolar follicles (01), advanced perinucleolar follicles (02) and pre-vitellogenic follicles (03) (see Figure 3B); advanced maturation/mature - F3= ovaries of maximum volume, with numerous vitellogenic follicles (O4) visible to the naked eye, dark brown in colour, besides having follicles at all developmental stages (see Figure 3C); partially spawned - F4A= flaccid, haemorrhagic ovaries with follicles at all developmental stages, besides post-ovulatory follicles (see Figure 3D-F) and totally spawned ovaries - F4B= very flaccid and haemorrhagic, histologically containing 01,02 , and final atretic follicles (see Figure 3E-G).

For males, the following macro and microscopic features of each maturation stages were identified: initial maturation - M2= whitish testicles, containing a small amount of spermatozoa and seminiferous tubules wall with cysts of spermatogenic cells in all developmental stages (see Figure 4A); advanced maturation/mature - M3= testicles reach the maximum volume, are milky-white in colour and presenting the lumen of seminiferous tubules filled with spermatozoa (see Figure 4B); partially spent - M4A= testicles are flaccid, haemorrhagic, with translucent and milky-white areas, seminiferous tubules' lumen partially empty, containing few spermatozoa (see Figure 4C). Resting M1 and totally spent males -M4B were not captured in present study.

\subsection{Reproductive activity}

Females and males in reproductive activity, stages 2 , 3 , and $4 \mathrm{~A}$, were recorded throughout the year in both sampling sections. The long reproductive period and the presence of partially spawned females with post-ovulatory follicles and follicles in all developmental stages indicate that the species present batch spawning of the multiple type. In section $1,66 \%$ of females and $29 \%$ of males were in advanced maturation stage. In section 2, $49 \%$ of females and $24 \%$ of males were in advanced maturation. In general, this species presented reproductive activity in both sampled sections (as shown in Figure 5). 


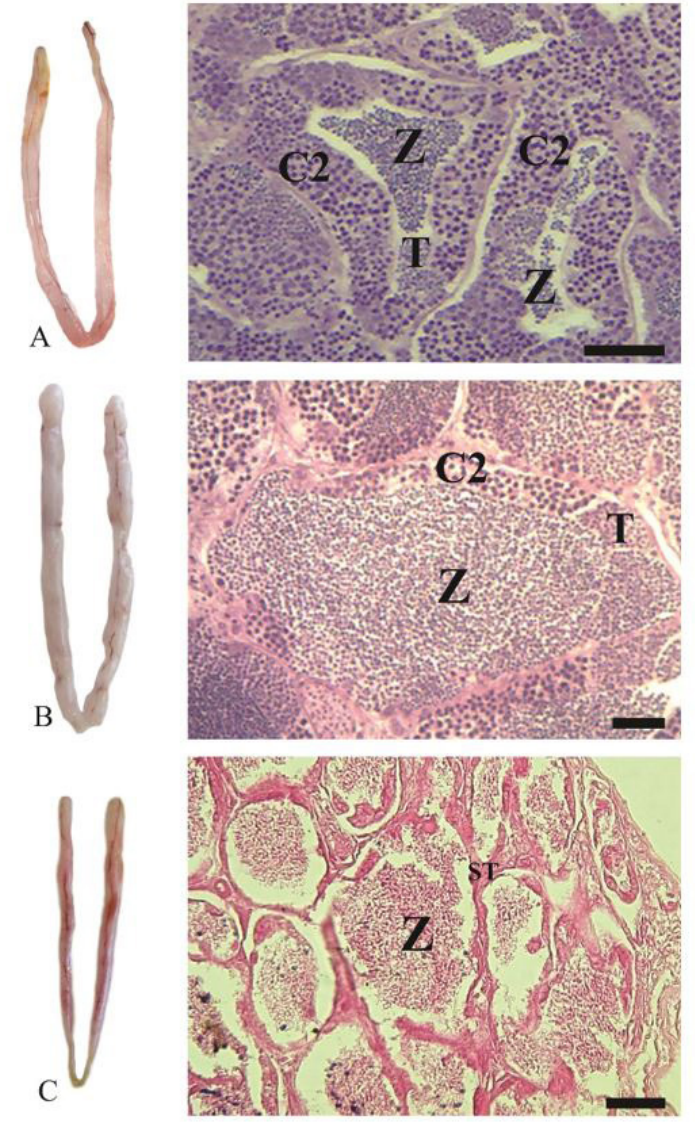

Figure 4. Testis in different maturation stages and respective transversal sections stained by HE. (A) early maturation, (B) advanced maturation/mature, $(C)$ partially spent; $Z=$ spermatozoa; $\mathrm{C} 2=$ secondary spermatocytes $\mathrm{T}=$ spermatids; $\mathrm{ST}=$ seminiferous tubules. Scale bars represent $A=100 \mu \mathrm{m}, \mathrm{B}=200 \mu \mathrm{m}$ and $\mathrm{C}=500 \mu \mathrm{m}$.

\section{Discussion}

The results of this study suggest that the alterations in water parameter immediately downstream of Três Marias Dam influence the reproductive potential of a non-migratory fish $A$. lacustris. This influence has already been shown by other authors studying migratory species (Sato et al., 2005; Thomé et al., 2012) and small forage fish (Normando et al., 2014). However, unlike migratory and forage fishes, $A$. lacustris maintained the reproductive activity, even with different performance, in both sections analysed in São Francisco River. Similar to our results, the impacts in aquatic organisms due to the release of colder water, with low concentration of dissolved oxygen, were also detected in others dammed rivers, such as: Serrasalmus brandtii from São Francisco River, Brazil (Bazzoli et al., 2019); aquatic invertebrate community from South African Rivers (Mantel et al., 2010); and other several fish species in USA rivers (Graf, 2006; Donaldson et al., 2008).

Regarding to biometry results, no significant differences in weight and length of the specimens was observed between the two sections. The standardization of the sample in the same size class, generates greater reliability of the data in the comparative studies, since in fish several reproductive parameters can be influenced by weight and length, such as fecundity, follicle diameter, gonadal volume and sperm production (Benejam et al., 2010; Muchlisin et al., 2011; Paschoalini et al., 2019).

Acestrorhynchus lacustris from both sections presented reproductive activity concentrated in the spring and summer, however the presence of mature specimens in all seasons was detected, a common feature for non-migratory fish from tropical environments (Lowe-McConnell, 1987). This species showed reproductive activity during almost the whole year as observed by Bazzoli and Godinho (1991) who studied the reproductive biology of the same species in a lentic environment, i.e. Três Marias reservoir. Similar to our data, the absence of the resting and fully spent males was also noted in a lentic environment (Bazzoli and Godinho, 1991), which may be indicative of a fast gonad recovery (recrudescence period) in dogfish males (Rinchard and Kestemont, 1996). In females of A. lacustris, four diameter classes of vitellogenic follicle were observed, indicating an asynchronous folliculogenesis and corroborating with observations in other non-migratory teleost (Armstrong and Witthames, 2012; Bazzoli et al., 2019; Melo et al., 2011). Fish with these characteristics generally have greater biological plasticity, greater tolerance to variations in the environmental conditions when compared to fish with seasonal reproductive activity, such as the migratory species (Campos-Mendoza et al., 2004; Godinho et al., 2009; Sato et al., 2005; Thomé et al., 2012). However, in present study we detected some alterations in reproductive parameters of A. lacustris in both sexes from section 1 .

The Fulton's condition factor and GSI are frequently used to asses environmental quality, since the body growth and gonads development can be influenced by the environmental conditions (Thomé et al., 2012; Yoda and Yoneda, 2009). Fulton's condition factor is derived from the consideration that for a group of individuals of the same size, those weighing more are in better condition (Abujanra et al., 2009). However, in the present study no significant differences was observed in the weight and size of males and females from both sections, a fact that may explain the absence of significant difference in the condition factor. On the other hand, we observed statistical differences in mean values of GSI between fish from the two sections analysed. The highest growth of the ovaries and testicles of fish from section 2 is similar to that observed for migratory species in the same study area (Sato et al., 2005; Arantes et al., 2010; Weber et al., 2013). Furthermore, in females was observed lower size in the vitellogenic follicle diameter of fish caught in section 1, corroborating that observed by Sato et al. (2005) and Arantes et al. (2010) in a total spawning Neotropical species; Normando et al.(2014) in non-migratory forage species; and Bazzoli et al. (2019) in others non-migratory species. The vitellogenic follicle diameter is reported as an important parameter related to reproductive fitness because larger follicles produce offspring with more energy reserves (Kinnison et al., 1998; Kolm and Ahnesjö, 2005; Lubzens et al., 2010). 

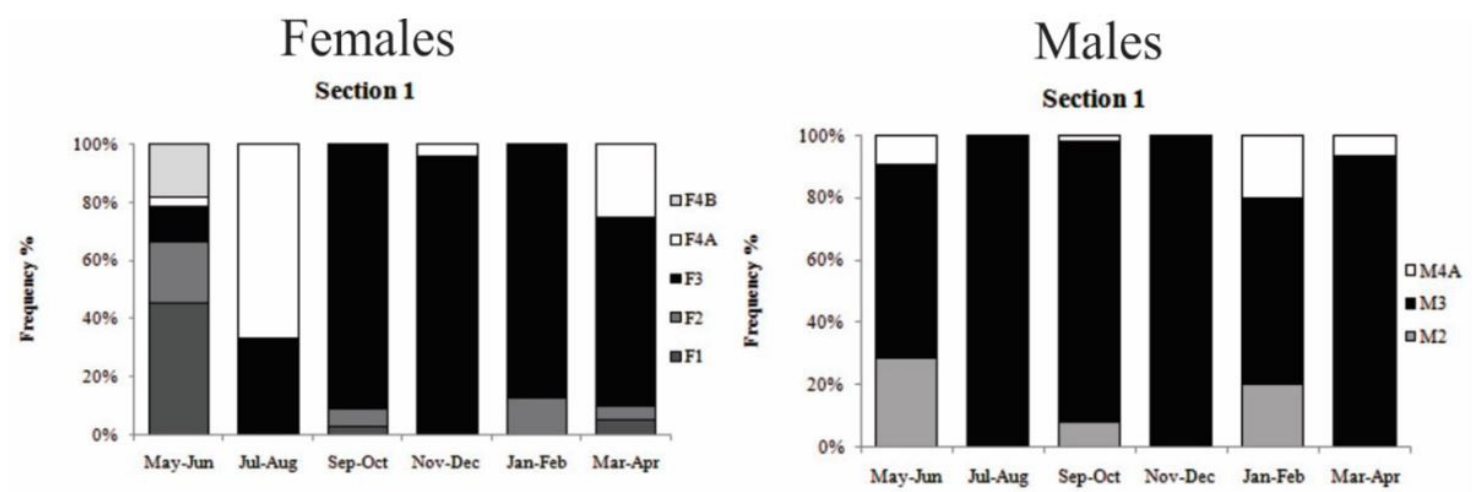

Section 2
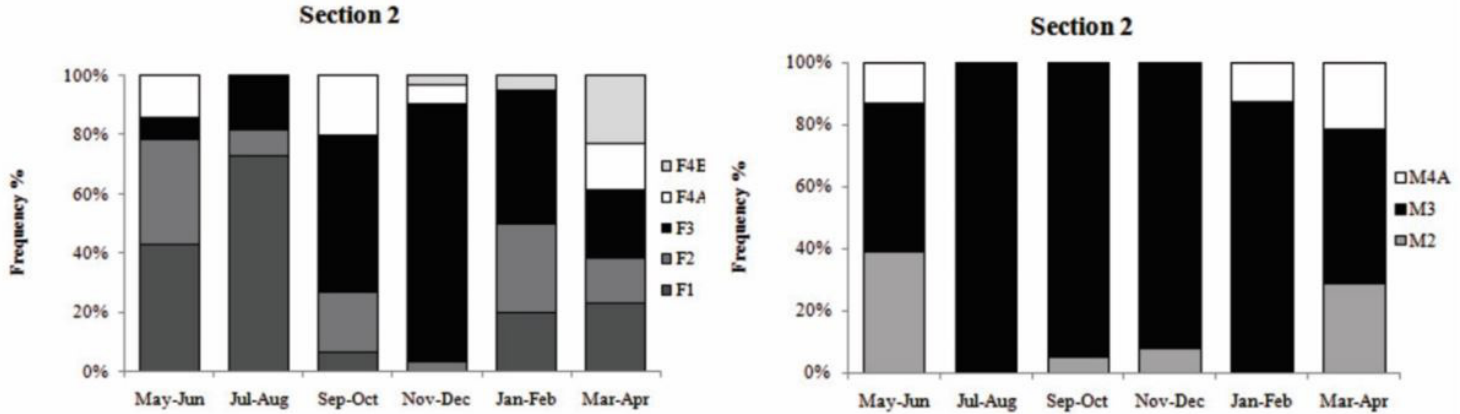

Figure 5. Frequency of the maturation stages of the A. lacustris collected in two sections on the São Francisco River downstream from the Três Marias Dam. Gonadal maturation stages of females: F1= resting, F2= initial maturation, F3= advanced maturation/mature, $\mathrm{F} 4 \mathrm{~A}=$ partially sapawned and $\mathrm{F} 4 \mathrm{~B}=$ totally sapawned; and males: $\mathrm{M} 2=$ initial maturation, $\mathrm{M} 3=$ advanced maturation/mature and $\mathrm{M} 4 \mathrm{~A}=$ partially spent.

Fecundity is reported as a parameter which is strongly linked to the environmental conditions (Armstrong and Witthames, 2012). Food availability and water temperature are reported as major factors capable of influencing the reproductive potential through the number and diameter of vitellogenic follicles (Armstrong and Witthames, 2012; Kinnison et al., 1998; Yoda and Yoneda, 2009). In the present study, batch fecundity showed statistically differences between fish collected from the two sampling sections, indicating that the number of vitellogenic follicles in ovaries was negatively affected by the water conditions in section 1 .

In an integrated analysis of the results, our data showed that unlike migratory species (Arantes et al., 2010; Perini et al., 2013), the non-migratory species $A$. lacustris, maintain their reproductive activity even in environments with lower temperature, dissolved oxygen and flow, suggesting a greater tolerance for environmental changes than migratory fish. However, even though it is considered a more resistant species, these alterations in the physical and chemical parameters of water reflected the decrease in the reproductive fitness of this species, fact that may influence in a worse health status of the offspring and affect the maintenance and conservation of this species in the São Francisco River.

\section{Conclusions}

The results of this study showed that a non-migratory species A. lacustris, with a multiple spawner/spermiation reproductive strategy, presented reproductive parameters altered in the section 1 downstream from the Três Marias Dam, where the physical and chemical conditions of the water are unfavourable to fish reproduction. In both sexes was noted a decrease in gonadal volume, and females showed lower values of follicle diameter and fecundity, when compared to section 2, confirming that the impact of dams also occurs on non-migratory fish.

\section{Acknowledgements}

The authors thank the partnership of CEMIG-GT/ CODEVASF. This work had the financial support of the Coordenação de Aperfeiçoamento de Pessoal de Nível Superior (CAPES) under grant (Finance code-001); Conselho Nacional de Desenvolvimento Científico e Tecnológico (CNPq) under grant (306946/2016-5 and 407719/2016-4); and Fundação de Amparo à Pesquisa do Estado de Minas Gerais (FAPEMIG) under grant (APQ03232-15).

\section{References}

ABUJANRA, F., AGOSTINHO, A.A. and HAHN, N.S., 2009. Effects of the flood regime on the body condition of fish of different trophic guilds in the Upper Paraná River floodplain, Brazil. Brazilian Journal of Biology = Revista Brasileira de Biologia, vol. 
69, no. 2, suppl., pp. 469-479. http://dx.doi.org/10.1590/S151969842009000300003. PMid:19738954.

AGOSTINHO, A.A., PELICICE, F.M. and GOMES, L.C., 2008. Dams and the fish fauna of the Neotropical region: impacts and management related to diversity and fisheries. Brazilian Journal of Biology = Revista Brasileira de Biologia, vol. 68, no. 4, suppl., pp. 1119-1132. PMid:19197482.

ARANTES, F.P., SANTOS, H.B., RIZZO, E., SATO, Y. and BAZZOLI, N., 2010. Profiles of sex steroids, fecundity, and spawning of the curimatã-pacu Prochilodus argenteus in the São Francisco River, downstream from the Três Marias Dam, Southeastern Brazil. Animal Reproduction Science, vol. 118, no. 2-4, pp. 330-336. http://dx.doi.org/10.1016/j.anireprosci.2009.07.004. PMid:19683404.

ARENZON, A., LEMOS, C.A. and BOHRER, M.B.C., 2002. The influence of temperature on the embryonic development of the annual fish Cynopoecilus melanotaenia (Cyprinodontiformes, Rivulidae). Brazilian Journal of Biology = Revista Brasileira de Biologia, vol. 62, no. 4B, pp. 743-747. http://dx.doi.org/10.1590/S151969842002000500002. PMid:12659024.

ARMSTRONG, M.J. and WITTHAMES, P.R., 2012. Developments in understanding of fecundity of fish stocks in relation to egg production methods for estimating spawning stock biomass. Fisheries Research, vol. 117-118, pp. 35-47. http://dx.doi. org/10.1016/j.fishres.2010.12.028.

BAZZOLI, N. and GODINHO, H.P., 1991. Reproductive biology of the Acestrorhynchus lacustris (Reinhardt, 1874) (Pisces, Characidae) from Três Marias Reservoir, Brazil. Zoologischer Anzeiger, vol. 226, pp. 285-297.

BAZZOLI, N., SILVA, V.E.S., MARCON, L., SANTIAGO, K.B., SANTOS, J.E. and RIZZO, E., 2019. The influence of a large reservoir on the reproductive activity of the white piranha, Serrasalmus brandtii (Lütken, 1875) in Southeast Brazil. Biota Neotropica, vol. 19, no. 2, pp. 1-8. http://dx.doi.org/10.1590/1676-0611bn-2018-0580.

BENEJAM, L., BENITO, J. and GARCÍA-BERTHOU, E., 2010. Decreases in condition and fecundity of freshwater fishes in a highly polluted reservoir. Water, Air, and Soil Pollution, vol. 210, no. 1-4, pp. 231-242. http://dx.doi.org/10.1007/s11270-009-0245-z.

CAMPOS-MENDOZA, A., MCANDREW, B.J., COWARD, K. and BROMAGE, N., 2004. Reproductive response of Nile tilapia (Oreochromis niloticus) to photoperiodic manipulation: effects on spawning periodicity, fecundity and egg size. Aquaculture, vol. 231, no. 1-4, pp. 299-314. http://dx.doi.org/10.1016/j. aquaculture.2003.10.023.

CARVALHO, P., PASCHOALINI, L., SANTOS, G.B., RIZZO, E. and BAZZOLI, N., 2009. Reproductive biology of Astyanax fasciatus (Pisces: Characiformes) in a reservoir in southeastern Brazil. Journal of Applied Ichthyology, vol. 25, no. 3, pp. 306-313. http://dx.doi. org/10.1111/j.1439-0426.2009.01238.x.

CETRA, M. and PETRERE JUNIOR, M., 2006. Fish-assemblage structure of the Corumbatai river basin, São Paulo State, Brazil: characterization and anthropogenic disturbances. Brazilian Journal of Biology = Revista Brasileira de Biologia, vol. 66, no. 2A, pp. 431-439. http://dx.doi.org/10.1590/S151969842006000300007. PMid:16862296.

DOMINGOS, F.F.T., THOMÉ, R.G., ARANTES, F.P., CASTRO, A.C.S., SATO, Y., BAZZOLI, N. and RIZZO, E., 2012. Assessment of spermatogenesis and plasma sex steroids in a seasonal breeding teleost: a comparative study in an area of influence of a tributary, downstream from a hydroelectric power dam, Brazil. Fish Physiology and Biochemistry, vol. 38, no. 6, pp. 1709-1719. http://dx.doi.org/10.1007/s10695-012-9668-3. PMid:22688450.
DONALDSON, M.R., COOKE, S.J., PATTERSON, D.A. and MACDONALD, J.S., 2008. Cold shock and fish. Journal of Fish Biology, vol. 73, no. 7, pp. 1491-1530. http://dx.doi.org/10.1111/j.10958649.2008.02061.x.

FERNANDES, I.M., BASTOS, Y.F., BARRETO, D.S., LOURENÇO, L.S. and PENHA, J.M., 2016. The efficacy of clove oil as an anaesthetic and in euthanasia procedure for small-sized tropical fishes. Brazilian Journal of Biology = Revista Brasileira de Biologia, vol. 77, no. 3, pp. 444-450. http://dx.doi.org/10.1590/1519-6984.15015. PMid:27683808.

GODINHO, A.L., LAMAS, I.R. and GODINHO, H.P., 2009. Reproductive ecology of Brazilian freshwater fishes. Environmental Biology of Fishes, vol. 87, no. 2, pp. 143-162. http://dx.doi.org/10.1007/ s10641-009-9574-4.

GRAF, W.L., 2006. Downstream hydrologic and geomorphic effects of large dams on American rivers. Geomorphology, vol. 79, no. 3-4, pp. 336-360. http://dx.doi.org/10.1016/j.geomorph.2006.06.022.

HAHN, N.S., DELARIVA, R.L. and LOUREIRO, V.E., 2000. Feeding of Acestrorhynchus lacustris (Characidae): a post impoundment studies on Itaipu reservoir, upper Paraná River, PR. Brazilian Archives of Biology and Technology, vol. 43, no. 2, pp. 207-213. http://dx.doi.org/10.1590/S1516-89132000000200010.

KINNISON, M.I., UNWIN, M.J., HERSHBERGER, W.K. and QUINN, T.P., 1998. Egg size, fecundity, and development rate of two introduced New Zealand chinook salmon (Oncorhynchus tshawytscha) populations. Canadian Journal of Fisheries and Aquatic Sciences, vol. 55, no. 8, pp. 1946-1953. http://dx.doi. org/10.1139/f98-074.

KOLM, N. and AHNESJÖ, I., 2005. Do egg size and parental care coevolve in fishes? Journal of Fish Biology, vol. 66, no. 6, pp. 1499-1515. http://dx.doi.org/10.1111/j.0022-1112.2005.00777.x.

LIZAMA, M.D.L.A.P. and AMBROSIO, A.M., 2002. Condition factor in nine species of fish of the Characidae family in the upper Paraná River floodplain, Brazil. Brazilian Journal of Biology = Revista Brasileira de Biologia, vol. 62, no. 1, pp. 113-124. http:// dx.doi.org/10.1590/S1519-69842002000100014. PMid:12185911.

LOWE-MCCONNELL, R.H., 1987. Ecological studies in tropical fish communities. Cambrigde: Cambridge University Press. http:// dx.doi.org/10.1017/CBO9780511721892.

LUBZENS, E., YOUNG, G., BOBE, J. and CERDÀ, J., 2010. Oogenesis in teleosts : how fish eggs are formed? General and Comparative Endocrinology, vol. 165, no. 3, pp. 367-389. http://dx.doi. org/10.1016/j.ygcen.2009.05.022. PMid:19505465.

MANTEL, S.K., MULLER, N.W. and HUGHES, D.A., 2010. Ecological impacts of small dams on South African rivers part 2: biotic response: abundance and composition of macroinvertebrate communities. Water SA, vol. 36, no. 3, pp. 361-370.

MELO, R.M.C., FERREIRA, C.M., LUZ, R.K., SATO, Y., RIZZO, E. and BAZZOLI, N., 2011. Comparative oocyte morphology and fecundity of five characid species from São Francisco River basin, Brazil. Journal of Applied Ichthyology, vol. 27, no. 6, pp. 1332-1336. http://dx.doi.org/10.1111/j.1439-0426.2011.01876.x.

MENEZES, N.A., 2003. Family Acestrorhynchidae In: R. E. REIS, S. O. KULLANDER and C. J. FERRARIS, eds. Check list of the freshwater fishes of South and Central America. Porto Alegre: EDIPUCRS, $231 \mathrm{p}$.

MUCHLISIN, Z.A., MUSMAN, M., FADLI, N. and NOR SITI-AZIZAH, M., 2011. Fecundity and spawning frequency of rasbora tawarensis (Pisces: Cyprinidae) an endemic species from Lake Laut Tawar, Aceh, Indonesia. AACL Bioflux, vol. 4, no. 3, pp. 273-279.

NORMANDO, F.T., SANTIAGO, K.B., GOMES, M.V.T., RIZZO, E. and BAZZOLI, N., 2014. Impact of the Três Marias Dam on the reproduction of the forage fish Astyanax bimaculatus and A. 
fasciatus from the São Francisco River, downstream from the dam, southeastern Brazil. Environmental Biology of Fishes, vol. 97, no. 3, pp. 309-319. http://dx.doi.org/10.1007/s10641-013-0153-3.

OLDEN, J.D. and NAIMAN, R.J., 2010. Incorporating thermal regimes into environmental flows assessments: modifying dam operations to restore freshwater ecosystem integrity. Freshwater Biology, vol. 55, no. 1, pp. 86-107. http://dx.doi. org/10.1111/j.1365-2427.2009.02179.x.

PASCHOALINI, A.L., SAVASSI, L.A., ARANTES, F.P., RIZZO, E. and BAZZOLI, N., 2019. Heavy metals accumulation and endocrine disruption in Prochilodus argenteus from a polluted neotropical river. Ecotoxicology and Environmental Safety, vol. 169, pp. 539-550. http://dx.doi.org/10.1016/j.ecoenv.2018.11.047. PMid:30476816.

PASCHOALINI, A.L., PERINI, V.R., RIBEIRO, D.M., FORMAGIO, P.S., RIZZO, E. and BAZZOLI, N., 2013. Reproduction of pimelodus maculatus (Siluriformes: Pimelodidae) in three section of Grande river basin, Downstream Porto Colombia Dam, South-Eastern Brazil. Neotropical Ichthyology, vol. 11, no. 3, pp.615-623. http:// dx.doi.org/10.1590/S1679-62252013000300015.

PERINI, V.R., PASCHOALINI, A.L., CRUZ, C.K., ROCHA, R.C., SENHORINI, J.A., RIBEIRO, D.M., FORMAGIO, P.S., BAZZOLI, N. and RIZZO, E., 2013. Profiles of sex steroids, fecundity and spawning of a migratory characiform fish from the Paraguay-Paraná basin: A comparative study in a three-river system. Fish Physiology and Biochemistry, vol. 39, no. 6, pp. 1473-1484. http://dx.doi. org/10.1007/s10695-013-9800-z. PMid:23616136.

PONTON, D., 1998. Fish juveniles of the Sinnamary River (French Guiana, South America): downstream effects immediately after Petit-Saut dam closure. Internationale Vereinigung für Theoretische und Angewandte Limnologie: Verhandlungen, vol. 26, no. 5, pp. 2314. http://dx.doi.org/10.1080/03680770.1995.11901161.
RINCHARD, J. and KESTEMONT, P., 1996. Comparative study of reproductive biology in single- and multiple-spawner cyprinid fish. I. Morphological and histological features. Journal of Fish Biology, vol. 49, no. 5, pp. 883-894. http://dx.doi. org/10.1111/j.1095-8649.1996.tb00087.x.

SATO, Y., BAZZOLI, N., RIZZO, E., BOSCHI, M.B. and MIRANDA, M.O.T., 2005. Influence of the Abaeté River on the reproductive success of the neotropical migratory teleost Prochilodus argenteus in the São Francisco River, downstream from the Três Marias Dam, southeastern Brazil. River Research and Applications, vol. 21, no. 8, pp. 939-950. http://dx.doi.org/10.1002/rra.859.

THOMÉ, R.G., DOMINGOS, F.F.T., SANTOS, H.B., MARTINELLI, P.M., SATO, Y., RIZZO, E. and BAZZOLI, N., 2012. Apoptosis, cell proliferation and vitellogenesis during the folliculogenesis and follicular growth in teleost fish. Tissue \& Cell, vol. 44, no. 1, pp. 54-62. http://dx.doi.org/10.1016/j.tice.2011.11.002. PMid:22153985.

WEBER, A.A., NUNES, D.M.F., GOMES, R.Z., RIZZO, E., SANTIAGO, K.B. and BAZZOLI, N., 2013. Downstream impacts of a Dam and influence of a tributary on the reproductive success of Leporinus reinhardti in São Francisco River. Aquatic Biology, vol. 19, no. 2, pp. 195-200. http://dx.doi.org/10.3354/ab00531.

YI, Y., TANG, C., YANG, Z. and CHEN, X., 2014. Influence of Manwan Reservoir on fish habitat in the middle reach of the Lancang River. Ecological Engineering, vol. 69, pp. 106-117. http://dx.doi. org/10.1016/j.ecoleng.2014.03.026.

YODA, M. and YONEDA, M., 2009. Assessment of reproductive potential in multiple-spawning fish with indeterminate fecundity: a case study of yellow sea bream Dentex hypselosomus in the East China Sea. Journal of Fish Biology, vol. 74, no. 10, pp. 2338-2354. http://dx.doi.org/10.1111/j.1095-8649.2009.02246.x. PMid:20735557. 